\title{
Battery-Supercapacitor Hybrids: A Literature Review
}

\author{
Praanav Lodha \\ The Dhirubhai Ambani international school \\ praanav@icloud.com \\ Acknowledgement \\ paper.
}

Thank you for the guidance of Avery Baumann from John Hopkins University in the development of this research

\begin{abstract}
This literature review explains the construction and charge storage mechanisms in Lithium-ion batteries. Further, it elaborates on the electrode reactions in Lithium-ion batteries, and commonly used electrode materials and their structures. Different types of Lithium-based batteries' electrochemical performance were compared, in addition to other relevant differentiators. The energy storage mechanism in Supercapacitors is briefly touched upon - and the electrochemical performance of supercapacitors is compared with that of lithium-ion batteries. Battery supercapacitor hybrids are introduced, with a brief section on their development over the past two decades following explanations of the charge storage mechanism and construction of battery supercapacitor hybrids. Battery supercapacitor hybrids are then compared with existing electrochemical energy storage mechanisms and finally, two types of battery supercapacitor hybrids were discussed.
\end{abstract}

Index Terms - Battery-supercapacitor Hybrids, Comparative analysis, Lithium-ion battery, Supercapacitors

\section{INTRODUCTION}

Batteries are the primary means of energy storage in the contemporary, electricity-based world. With renewable sources of energy being the subject of intensive, global scale research, one problem presents itself above all others: where can we stock excess energy when the full combined capacity of power sources is not in use? Traditional means of energy generation involve burning fossil fuels to produce electricity, and when not needed he furnaces can function with minimal amounts of fuel as compared to their full production capacity. However, when renewable energy comes into play, we give up the ability to control the output power, with solar and wind farms depending on sunlight and wind speed respectively. This lack of control leads to the need for energy storage systems that fulfil a number of requirements: efficiency, energy density, power density, operating range and more importantly for large-scale applications such as powering entire cities cost per kWh of energy stored. Although the advent of new forms of energy storage, like gravity- based storage systems and heat-based systems are providing potential future alternatives, these technologies will likely remain concepts and prototypes for the next decade. Accordingly, we need a means of storing energy that can be developed rapidly, whose concept has already been proven, and one that can be manufactured at a large scale using existing technologies at a reasonable cost. Lithium based batteries are the first choice that comes to mind, however, the lower power density, and high cost inhibits continuous manufacturing. Moreover, their manufacture is unsustainable due to the relative rarity of naturally occurring lithium deposits. Supercapacitors (SCs) are the second means one deliberates, but, the inherent high self-discharge rates combined with low energy density make them an unviable alternative for long term storage. However, in 2001, Amatucci et $\mathrm{al}^{1}$. created a device that combines the energy density of a lithium-ion battery (LIB) and the power density of a supercapacitor - a Battery Supercapacitor Hybrid. These devices can provide a viable means to store energy, combing the best aspects of both LIBs and SCs in one device. Recent developments have allowed BSHs to be constructed from various types of batteries, namely $\mathrm{Na}-$-ion $\mathrm{BSHs}^{2}$ as constructed by Kuratani et al. and Alkaline BSHs. Although still in a relatively nascent stage of their development, BSHs have shown huge potential - and are the focus of this paper.

\section{LITERATURE REVIEW}

\section{ENERGY STORAGE IN A GENERIC ALKALINE CELL:}

A battery creates a potential difference between its electrodes. It does this by creating a flow of electrons between the anode and cathode - through an external connection when a circuit is completed- which are separated by a fibrous barrier that allows only the flow of cations. On this separator is an electrolyte, and a core made of the cathode material. the zinc is in powder form to improve surface area thus reducing internal resistance. Both terminals are isolated from each other, generally by a nylon cap at the bottom end of the cell. This layout is shown in figure 1. The combination of the materials - manganese dioxide as the cathode and a gel which has zinc powder as the anode (in alkaline batteries) - causes a reaction. The zinc ion in the battery is oxidized and this releases electrons, which collect at the cathode. Simultaneously, the anode is reduced and with the repetition of these two reactions, there is an electron build up at the cathode which creates a potential difference across the terminals. When connected, the flow of electrons generates current and thus provides energy. When not in use, the battery stores energy chemically as described above. 


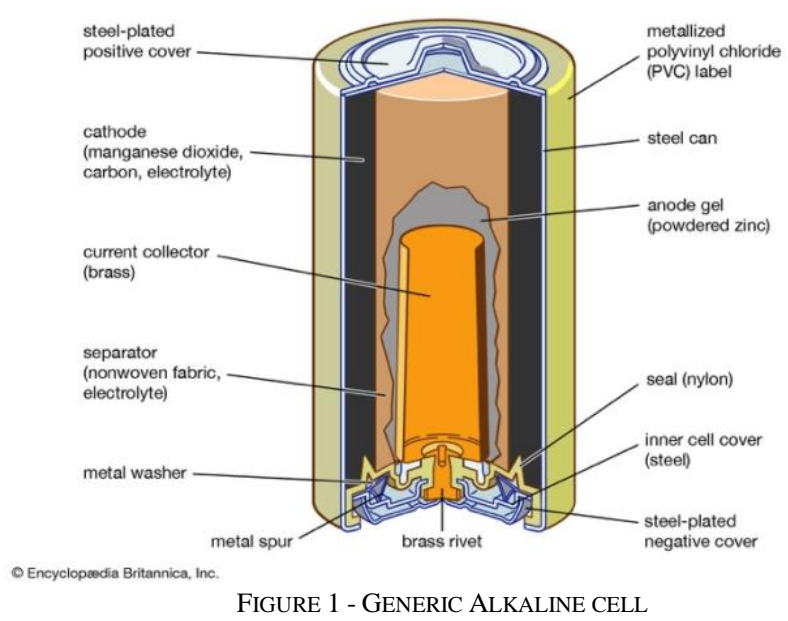

ENERGY STORAGE IN A LITHIUM-ION BATTERY:

\section{CONSTRUCTION:}

A generic li-ion battery consists of an anode made of copper coated with graphite (recent technological advancements have led to the use of graphene). Its cathode is a lithium-based compound, normally $\mathrm{LiCoO} 2$ or $\mathrm{LiFePO} 4$. The anode and cathode are separated by an electrolyte, in which there is a dielectric separator. This layout is as shown in figure 2 .

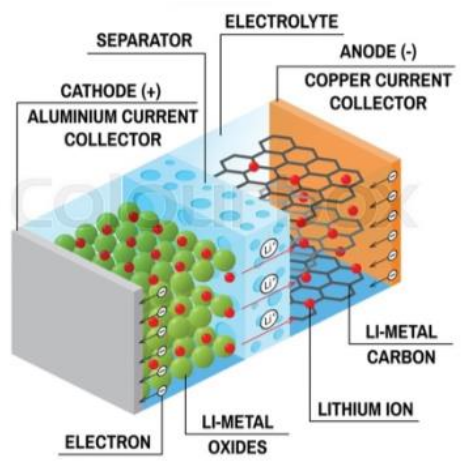

FIGURE 2 - CONSTRUCTION OF A LI-ION BATTERY

For optimal packing efficiency into a cell, strips of thin layers are rolled into a cylindrical cell using the 'swiss roll method', as shown in figure 3 . The layout is extremely thin and compact, the diagram above enlarging the width of the electrodes and electrolyte significantly. This layout is still in use today due to its hyper-optimized design.

\section{WHY LITHIATED METAL OXIDES ARE USED:}

Lithium-ion batteries are lightweight and have a high energy density, and they can be recharged rapidly. The element's high electrochemical potential makes it a valuable component of high energy-density rechargeable lithium-ion batteries ${ }^{6}$. Additionally, lithium is the least dense and lightest metal, which means more lithium atoms or ions can fit into the same volume than any other solid element. Further, of all elements, lithium has the least ionization energy due to its electronic configuration, so a minimal

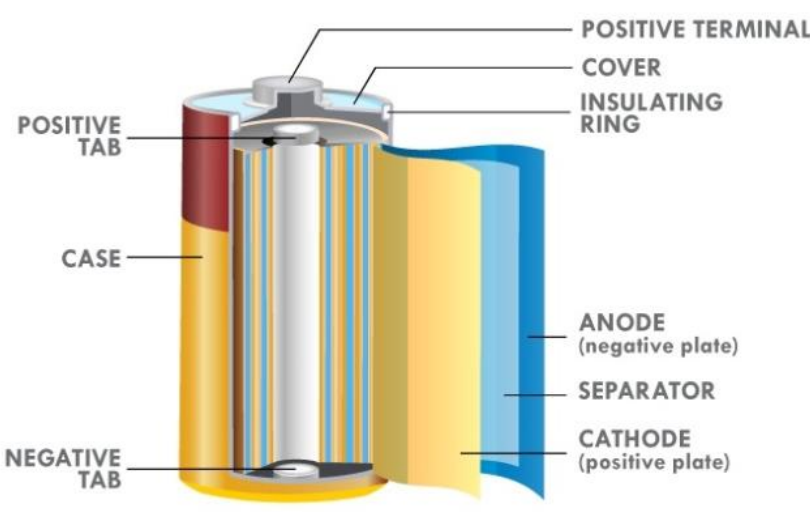

FIGURE 3 - SWISS ROLL METHOD OF PACKAGING A CELL

amount of energy is required to initiate the charge-discharge procedure. Lastly, lithium is highly reactive and this carries the implication that more energy can be stored in the bonds lithium forms than in any other element, which contributes to the high energy density of lithium batteries. To this end, lithiated metal oxides are ideal electrode material due to the fact that the most amount of energy and molecules can be squeezed into the same volume of space - maximising the electrochemical performance of a battery.

\section{CHARGE-DisCHARGE:}

During charge, ions from the cathode pass through the electrolyte and are transferred into the lithium graphite anode, where they intercalate with the layers of graphite. The separator prevents them from flowing back into the cathode to a large extent, which reduces the self-discharge rate greatly. When current is required and the terminals are connected, ions intercalated with the graphite first release one or more electrons, and these flow through the means of connection and return to the cathode, where the cathodic ion has also travelled, through the separator, and once the compound is re-formed, the battery is ready for charge. energy is stored in the lithiated metal oxide cathode in the form of the energy used to ionize that compound while charging -releasing the energy that caused ionization during discharge. This ionic movement can be visualized as in figure 4 .

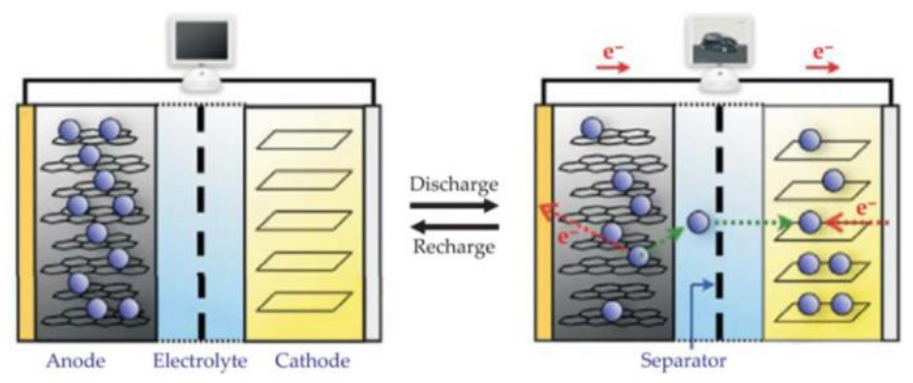

FIGURE 4 - A REPRESENTATION OF IONIC MOVEMENT DURING CHARGE AND DISCHARGE 


\section{i. $\quad$ At the cathode 7 :}

During discharge, lithium ions migrate from the anode through the electrolyte medium to the cathode, where they are incorporated into lithium cobalt oxide through the following reaction, which reduces cobalt from $\mathrm{a}+4$ to $\mathrm{a}+3$ oxidation state. During charge, the reaction is reversed.

$$
\mathrm{Li}_{1-x} \mathrm{CoO}_{2}(s)+x \mathrm{Li}^{+}+x e^{-} \rightarrow \mathrm{LiCoO}_{2}(s)
$$

ii. At the anode ${ }^{7}$ :

During discharge, lithium stays as $\mathrm{Li}+$ in the lithium-graphite anode, while the carbon is reduced through the following reaction, which is reversed during charge.

$$
\begin{gathered}
C_{6} L i \rightarrow 6 C+L^{+}+e^{-} \\
\text {(as graphite lattice) }
\end{gathered}
$$

\section{THE INTERCALATION MECHANISM:}

LIBs operate by storing energy through the variable intercalation of ions in the electrodes. This is achieved through two means. Firstly, the anode material is graphite (In newer batteries, this is graphene and research is being carried out where silicon-based anodes are being experimented with). Graphite is a form of carbon composed of layers of tightly bound carbon atoms whose layers are loosely held together, as shown in figure $5^{7}$. It is between these layers that lithium ions are intercalated and where they remain until discharge.

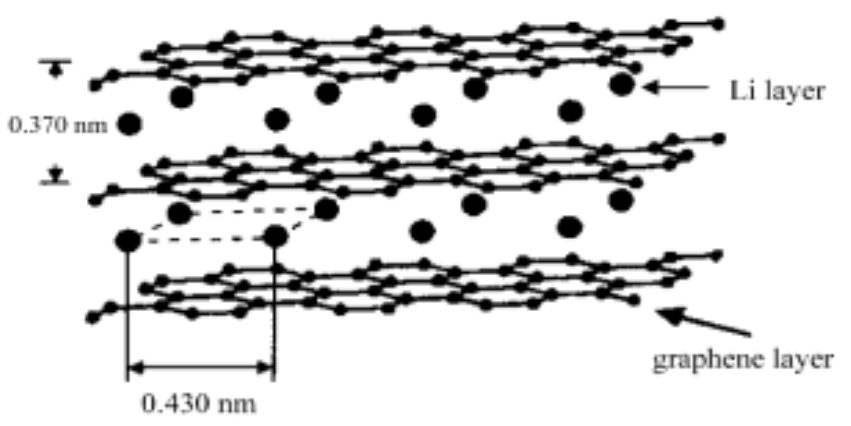

FIGURE 5 - VISUAL REPRESENTATION OF INTERCALATION

COMMONLY USED ELECTRODE MATERIALS:

\begin{tabular}{|l|c|c|c|c|}
\hline \multirow{2}{*}{ Electrode } & Material & Structure & $\begin{array}{l}\text { Average } \\
\text { Voltage } \\
\text { (V vs. Li) }\end{array}$ & $\begin{array}{l}\text { Practical } \\
\text { Capacity } \\
\text { (mAh/g) }\end{array}$ \\
\hline \multirow{3}{*}{ Cathodes } & LiCoO2 & Layered & $\sim 3.9$ & $\sim 140$ \\
\cline { 2 - 5 } & LiMnO2 & Spinel & $\sim 4.1$ & $\sim 120$ \\
\cline { 2 - 5 } Anodes & LiFePO4 & Olivine & $\sim 3.45$ & $\sim 160$ \\
\cline { 2 - 5 } & Graphite (LiC6) & Layered & $\sim 0.1$ & $\sim 360$ \\
\hline \multirow{2}{*}{ Li4Ti5O12 } & Spinel & $\sim 1.5$ & $\sim 175$ \\
\hline
\end{tabular}

TABLE 1 - COMMONLY USED CATHODE AND ANODE MATERIALS

\section{TYPES OF ELECTRODE STRUCTURES:}

The following section will display the different types of structures as introduced in table 1 .

i. $\quad$ Spinel Structure ${ }^{9,10}$ :
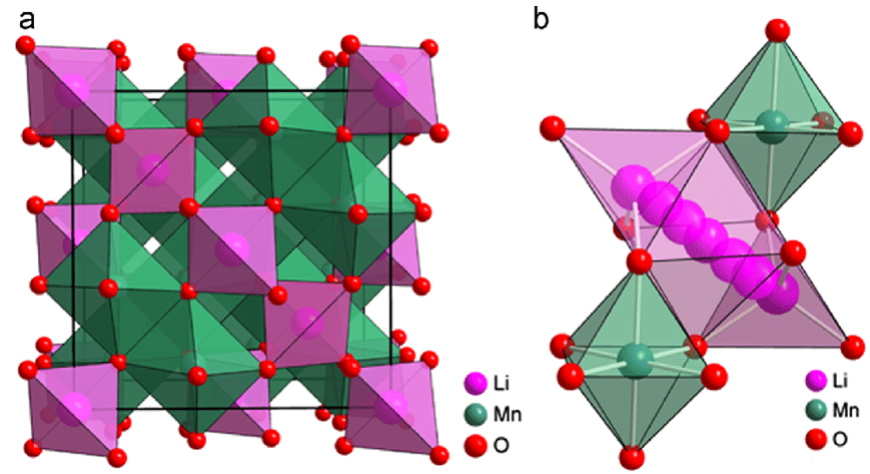

FIGURE 6 - (A) SPINEL STRUCTURE OF LIMN $_{2} \mathrm{O}_{4}$; (B) LITHIUM DIFFUSION PATHWAYS

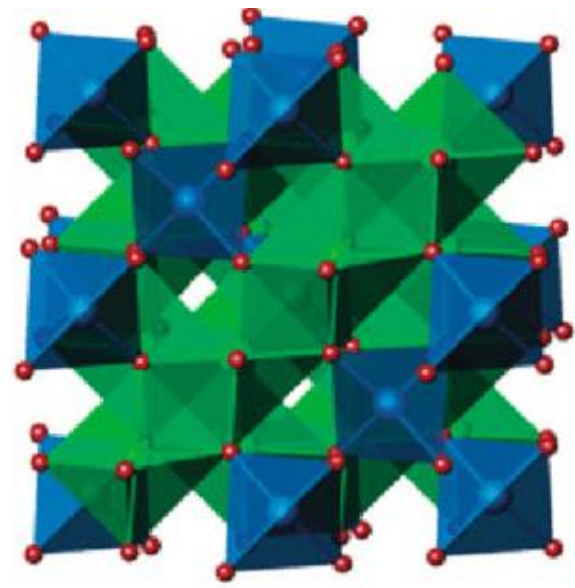

FIGURE 7 - $\mathrm{LI}_{4} \mathrm{TI}_{5} \mathrm{O}_{12}$ SPINEL STRUCTURE, BLUE OCTAHEDRA REPRESENT LITHIUM, GREEN OCTAHEDRA REPRESENT DISORDERED LITHIUM AND TITANIUM; RED SPHERES REPRESENT OXYGEN

ii. Layered Structure ${ }^{11,12}$ :

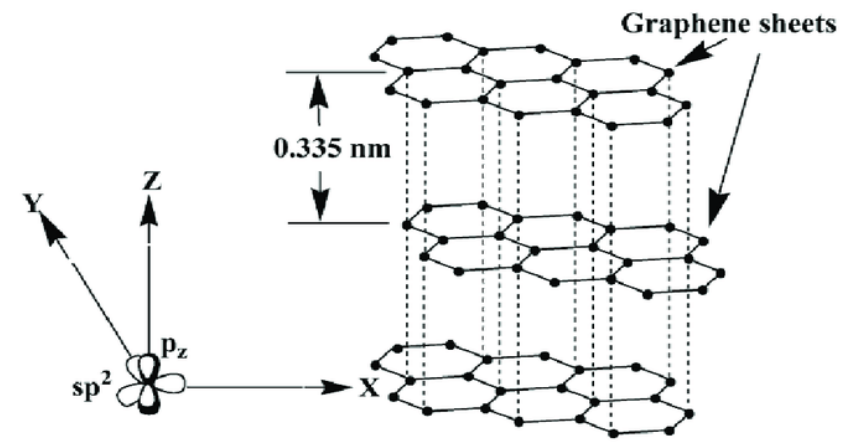

FIGURE 8 - LAYERED STRUCTURE IN GRAPHITE 


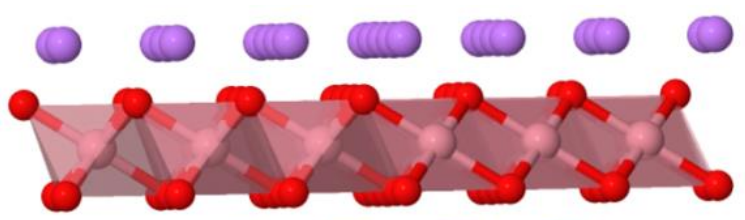

- $\infty \mathbb{C O}$
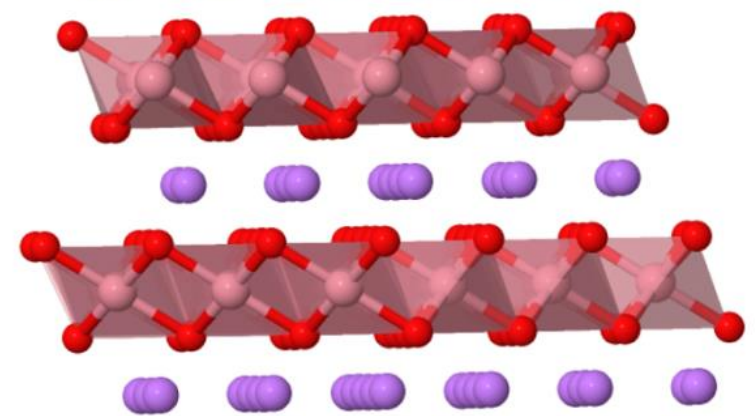

FIGURE 9 - LAYERED STRUCTURE OF $\mathrm{LICOO}_{2}$; RED SPHERES REPRESENT OXYGEN; PURPLE SPHERES REPRESENT LITHIUM; PEACH REPRESENT COBALT

iii. $\quad$ Olivine Structure ${ }^{13}$ :

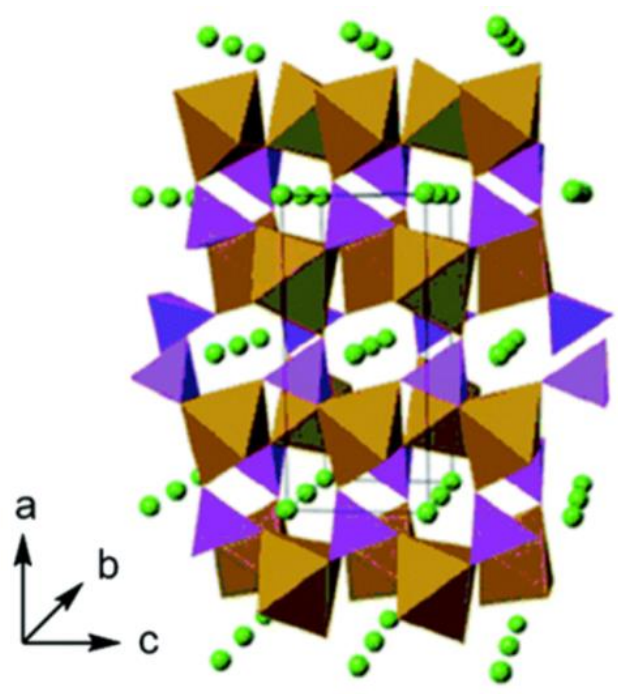

Figure 10 - OLIVINE Structure IN $\mathrm{LIFEPO}_{4}$

\section{FACTORS THAT AFFECT ELECTROCHEMICAL PERFORMANCE}

The chemical structure of the electrodes and electrolyte, as well as their micro-scale behaviours- like ionic conductivity affect the properties of the battery. These properties define the performance of the battery. The way a battery performs then goes on to alter its structure and chemistry - since a better performing battery will inevitably consume the reactive materials within it more rapidly than a lower performing one- resulting in a positive feedback loop of sorts. The factors that affect electrochemical performance of batteries are shown in figure $11^{14}$.

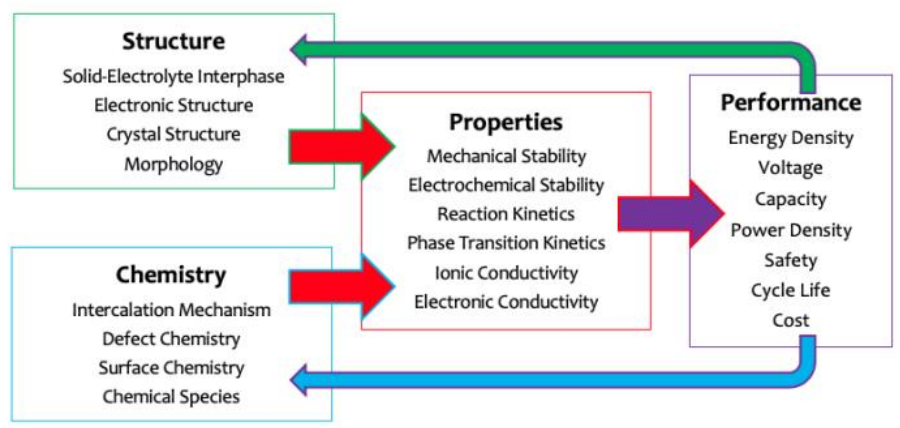

FIGURE 11 - FACTORS AFFECTING ELECTROCHEMICAL PERFORMANCE 


\section{ENERGY STORAGE IN SUPERCAPACITORS}

\section{ELECTROSTATIC ENERGY STORAGE}

Electrical energy is stored in supercapacitors via two storage principles, electrostatic double-layer capacitance and electrochemical pseudo-capacitance. Supercapacitors store less energy than batteries but release exponentially faster. They can also be charged faster than conventional batteries due to an inherent low energy density, and since energy is stored electrostatically, creating a charge difference at the terminals. When these terminals are connected, the oppositely charged particles quickly release from the plates they are ordered on and flow across extremely fast.

\section{ASYMMETRIC SUPERCAPACITORS}

Asymmetric supercapacitors (ASCs) are assembled using two dissimilar electrode materials that offer the distinct advantage of a wide operational voltage window, which significantly enhances their energy density. Generally, metal oxides are employed as one of the supercapacitor electrodes, whereby $\mathrm{RuO}_{2}, \mathrm{MnO}_{2}$, and $\mathrm{Ni}(\mathrm{OH})_{2}$ are the most commonly used materials ${ }^{15}$. Other materials can be used as the other electrode to fabricate ASCs, such as porous carbon. For example, ASCs employing aqueous electrolytes have potential windows of greater than $2.0 \mathrm{~V}$. The energy density of ASCs can reach almost $100 \mathrm{~W} \mathrm{~h} \mathrm{kg-1}$. Based on these features, a higher ASC energy density can be obtained by utilizing organic or ionic-liquid electrolytes, which have higher working voltages ${ }^{15}$. Moreover, Misra et al. ${ }^{16}$ reported a tandem ASC with a high working potential of $4.5 \mathrm{~V}$ to provide a wider voltage window, which had an energy density that was $61 \%$ higher than that of single ASCs.

\section{PSEUDOCAPACITORS}

Pseudocapacitors store electrical energy both faradaically and non-faradaically by electron charge transfer between electrode and electrolyte. A pseudo capacitor has a chemical reaction at both electrodes, unlike EDLCs where the electrical charge storage is stored electrostatically with no interaction between the electrode and the ions. the capacitance of a pseudo capacitor may be higher by a factor of 100 as a double-layer capacitance with the same electrode surface.

\section{COMPARING ENERgy STORAGE SYSTEMS}

\section{COMPARING DIFFERENT TYPES OF BATTERIES}

In order to display the characteristics that batteries constructed with different electrode materials have, data was first assembled from a variety of sources, then tabulated in table 2 . To provide a comparison for the benefits of the use of lithium, the same data was gathered for a $\mathrm{Zn}$-air battery as well.

As seen in table 2, LiS and Li-air batteries have a significant advantage over other types of batteries with respect to their theoretical specific energies - a measure of how much energy a battery contains in comparison to its weight. The best cycle livesdefined as the number of charge cycles a battery can be put through till it retains only $80 \%$ of its original capacity at a state of full charge, were exhibited by $\mathrm{Li}$-ion batteries and $\mathrm{Li}$-metal batteries. The cheapest type of lithium-based battery is the LiS, and the cheapest overall was the $\mathrm{Zn}$-air battery - costing $100 \$$ per $\mathrm{kWh}$. Of all the batteries compared, LiPo and Li-ion batteries are the most efficient - with energy efficiency defined as a measure of the energy that can be taken from the battery compared to the amount of energy that it was charged with beforehand. The specific energies and cycles lives are compared in figures 12 and 13 respectively.

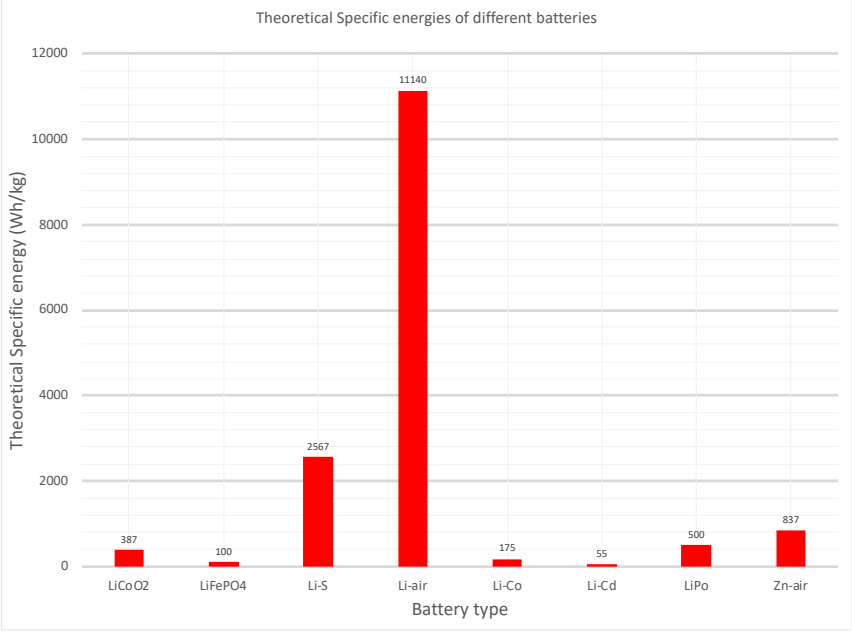

FIGURE 12 - COMPARING THEORETICAL SPECIFIC ENERGY DENSITIES OF DIFFERENT BATTERIES

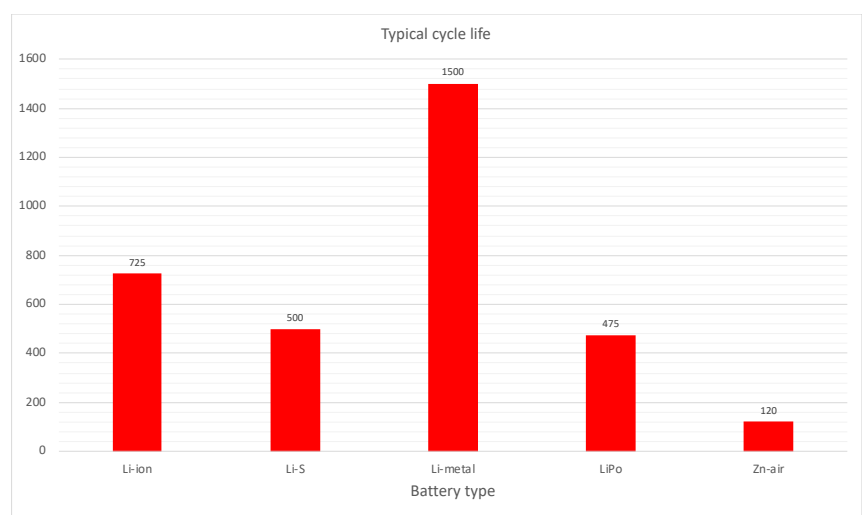

FIGURE 13 - CYCLE LIFE OF DIFFERENT BATTERIES 


\begin{tabular}{|c|c|c|c|c|c|c|c|c|c|}
\hline \multirow{2}{*}{$\begin{array}{l}\text { Battery type } \\
\text { sub-type }\end{array}$} & \multicolumn{2}{|l|}{ Li-ion } & \multirow{2}{*}{$\begin{array}{l}\text { Li-S } \\
\end{array}$} & \multicolumn{2}{|l|}{ Li-air } & \multicolumn{2}{|c|}{ Li-metal } & \multirow{2}{*}{$\begin{array}{l}\text { LiPo } \\
\end{array}$} & \multirow{2}{*}{ Zn-air } \\
\hline & LiCoO2 & LiFePO4 & & $\begin{array}{c}1^{\text {st }} \text { cycle } \\
\text { secondary } \\
\text { battery }\end{array}$ & $\begin{array}{l}2^{\text {nd }} \text { cycle } \\
\text { primary } \\
\text { battery }\end{array}$ & Li-Co & $\mathrm{Li}-\mathrm{Cd}$ & & \\
\hline $\begin{array}{l}\text { Theoretical } \\
\text { Specific energy } \\
\text { (Wh/kg) }\end{array}$ & $387^{17}$ & $100^{18}$ & $2567^{17}$ & $3582^{19}$ & $11140^{19}$ & $\begin{array}{l}150- \\
200^{20}\end{array}$ & $50-60^{20}$ & $500^{21}$ & $837^{22}$ \\
\hline $\begin{array}{l}\text { Typical cycle } \\
\text { life }\end{array}$ & \multicolumn{2}{|c|}{$250-1200^{23}$} & $500^{19}$ & $>10$ & 1 & \multicolumn{2}{|c|}{$1000-2000^{20}$} & $350-600$ & $120^{22}$ \\
\hline cost/kWh & 200 & $000 \$ 24$ & $200 \$ 25$ & & \multicolumn{2}{|c|}{$400 \$$} & $600 \$$ & $<100 \$^{22}$ \\
\hline applications & $\begin{array}{l}\text { Electri } \\
\text { Portab } \\
\text { grid-sc } \\
\text { storag }\end{array}$ & $\begin{array}{l}\text { Vehicles, } \\
\text { devices, } \\
\text { le power } \\
\text { systems, } \\
\text { tc }\end{array}$ & $\begin{array}{l}\text { See technical maturity } \\
\text { below }\end{array}$ & \multicolumn{2}{|c|}{$\begin{array}{c}\text { See technical maturity } \\
\text { below }\end{array}$} & \multicolumn{2}{|c|}{$\begin{array}{l}\text { cordless home } \\
\text { phones, } \\
\text { emergency } \\
\text { lighting }\end{array}$} & $\begin{array}{l}\text { Remote-controlled } \\
\text { vehicles, consumer } \\
\text { electronics }\end{array}$ & $\begin{array}{l}\text { hearing aids, } \\
\text { digital watches }\end{array}$ \\
\hline $\begin{array}{l}\text { energy } \\
\text { efficiency }\end{array}$ & \multicolumn{2}{|c|}{$70 \%-100 \%{ }^{23}$} & - & \multicolumn{2}{|c|}{ - } & \multicolumn{2}{|c|}{$\sim 88 \%{ }^{26}$} & $\begin{array}{c}>95 \% \text { (between } 20- \\
40 \circ \mathrm{C})^{27}\end{array}$ & $30-50 \%^{23}$ \\
\hline $\begin{array}{l}\text { operating } \\
\text { temperature } \\
\text { range }\end{array}$ & \multicolumn{2}{|c|}{$10^{\circ} \mathrm{C}-80^{\circ} \mathrm{C} \mathrm{C}$} & $10^{\circ} \mathrm{C}-60^{\circ} \mathrm{C}$ & \multicolumn{2}{|c|}{-} & \multicolumn{2}{|c|}{$15 \circ \mathrm{C}-45^{\circ} \circ \mathrm{C}$} & $5 \circ \mathrm{C}-80^{\circ} \mathrm{C}$ & $10 \circ \mathrm{C}-50 \circ \mathrm{C}$ \\
\hline Advantages & $\begin{array}{r}\text { Very hi } \\
\text { Very } \\
\text { Very h } \\
\text { and disc } \\
\text { no mer } \\
\text { Inhere } \\
\text { Rec } \\
\text { Lo } \\
\text { disc }\end{array}$ & $\begin{array}{l}\text { h capacity } \\
\text { ow ESR } \\
\text { h charge } \\
\text { large rates } \\
\text { ory effect } \\
\text { tly safer } \\
\text { clable } \\
\text { self- }^{\text {large }}{ }^{28}\end{array}$ & $\begin{array}{l}\text { Low cost } \\
\text { Non-toxic } \\
\text { Very high energy density } \\
\text { excellent performance at } \\
\text { room temperature } \\
\text { relatively lightweight } \\
\text { (approx. } 1000 \mathrm{~kg} / \mathrm{m}^{\wedge} 3 \text { ) }\end{array}$ & \multicolumn{2}{|c|}{$\begin{array}{l}\text { extremely high specific } \\
\text { energy } \\
\text { lightweight due to air } \\
\text { cathode }\end{array}$} & \multicolumn{2}{|c|}{$\begin{array}{l}\text { low internal } \\
\text { resistance } \\
\text { can supply high } \\
\text { surge currents } \\
\text { high cycle life }\end{array}$} & $\begin{array}{c}\text { relatively low } \\
\text { weight } \\
\text { high power delivery } \\
\text { high specific } \\
\text { capacity }\end{array}$ & $\begin{array}{l}\text { high energy } \\
\text { density } \\
\text { low cost } \\
\text { Low active } \\
\text { material } \\
\text { utilization }\end{array}$ \\
\hline Disadvantages & $\begin{array}{r}\text { High } \\
\text { Lower } \mathrm{f} \\
\text { high en } \\
\text { impa } \\
\text { usage } \\
\text { sensiti } \\
\text { temp } \\
\text { unus } \\
\text { cor } \\
\text { disc }\end{array}$ & $\begin{array}{l}\text { er cost } \\
\text { at voltage } \\
\text { ronmental } \\
\text { due to } \\
\text { f Cobalt } \\
\text { e to high } \\
\text { ratures } \\
\text { le after } \\
\text { plete } \\
\text { arge }^{28}\end{array}$ & $\begin{array}{l}\text { suffers from permanently } \\
\text { reduced life and } \\
\text { capacities under very } \\
\text { high discharge rates, } \\
\text { improper storage } \\
\text { environments, from } \\
\text { overcharging or from } \\
\text { complete discharge. } \\
\text { Moderate technical } \\
\text { maturity } \\
\text { Bad cycling stability }\end{array}$ & \multicolumn{2}{|c|}{$\begin{array}{l}\text { Still in early stages of } \\
\text { development } \\
\text { Will be at least 5-10 } \\
\text { years until commercial } \\
\text { availability } \\
\text { Very low cyclability }\end{array}$} & \multicolumn{2}{|c|}{$\begin{array}{l}\text { Low specific } \\
\text { capacity } \\
\text { High cost } \\
\text { Small } \\
\text { temperature } \\
\text { range in which } \\
\text { efficient }\end{array}$} & $\begin{array}{l}\text { risk of fire if charged } \\
\text { for a prolonged } \\
\text { period } \\
\text { tends to heat up } \\
\text { under high load } \\
\text { high cost }\end{array}$ & $\begin{array}{l}\text { low power } \\
\text { density } \\
\text { Poor cycling } \\
\text { stability of air } \\
\text { cathodes }\end{array}$ \\
\hline $\begin{array}{l}\text { Technical } \\
\text { Maturity }\end{array}$ & \multicolumn{2}{|c|}{$\begin{array}{c}\text { proven } \\
\text { Commercialized }\end{array}$} & $\begin{array}{l}\text { Not commercialized } \\
\text { More mature than Li-air, } \\
\text { less mature than Li-ion }\end{array}$ & \multicolumn{2}{|c|}{$\begin{array}{c}\text { In development phase } \\
\text { Not commercially } \\
\text { available }\end{array}$} & \multicolumn{2}{|c|}{$\begin{array}{c}\text { mature } \\
\text { commercialized }\end{array}$} & $\begin{array}{c}\text { mature } \\
\text { commercialized }\end{array}$ & $\begin{array}{c}\text { Mature } \\
\text { commercialized }\end{array}$ \\
\hline
\end{tabular}

TABLE 2 - COMPARING DIFFERENT TYPES OF BATTERIES ON THE BASIS OF ELECTRODE MATERIALS

\section{COMPARING LI-ION BATTERIES WITH ULTRACAPACITORS:}

In order to successfully show the advantages and disadvantages that Battery Supercapacitor Hybrids (BSHs) have as compared to both LIBs and Ultracapacitors (UCs), we must first compare LIBs and UCs by themselves. This comparison is carried out in table 3 and is represented visually in figures 14 and $15-$ alternatives to each other with an aim to improve the ease of reading.

As can be seen, the specific energy and energy density of LIBs is significantly higher than that of UCs. However, when their power densities and specific powers are compared, UCs far outperform LIBs. Further, the cycle life of UCs is exponentially greater than that of LIBs - in part due to the absence of a reactive electrochemical storage mechanism. UCs, partly due to their intricate construction and developing progress, in addition to the inherent low energy density - implying more UCs are needed for the same energy capacity, have a cost far greater than that of LIBs. However, UCs have little to no impact on the environment - with readily available carbon comprising the main raw material in their manufacture. LIBs on the other hand, require lithium and cobalt for their construction - elements that are scarce and expensive and whose extraction causes significant environmental damage. Both LIBs and UCs are similarly efficient, with the potential to be completely efficient, although the electrostatic charge storage mechanism in UCs leads to a significantly higher self-discharge rate. 


\begin{tabular}{|l|c|c|}
\hline & Li-lon Battery ${ }^{\mathbf{2 3}}$ & Ultracapacitors $^{\mathbf{2 3}}$ \\
\hline Specific Energy (Wh/kg) & $30-400$ & $0.7-85.6$ \\
\hline Specific Power (W/kg) & $8-2000$ & $5.44-100000$ \\
\hline Energy Density (Kwh/m^3) & $94-500$ & $1-35$ \\
\hline Power Density (KW/m^3) & $56.8-800$ & $15-4500$ \\
\hline Cycle life (cycles) & $250-1200$ & $10000-1000000$ \\
\hline Cost (US\$/kWh) & $200-4000$ & $300-20000$ \\
\hline Environmental Impact & High & Very Low \\
\hline Energy Efficiency & $70-100 \%$ & $65-99 \%$ \\
\hline Self-Discharge Rate (\% per day) & $2-3$ & $0.46-40$ \\
\hline
\end{tabular}

TABLE 3 - A COMPARISON BETWEEN LITHIUM-ION BATTERIES AND SUPERCAPACITORS

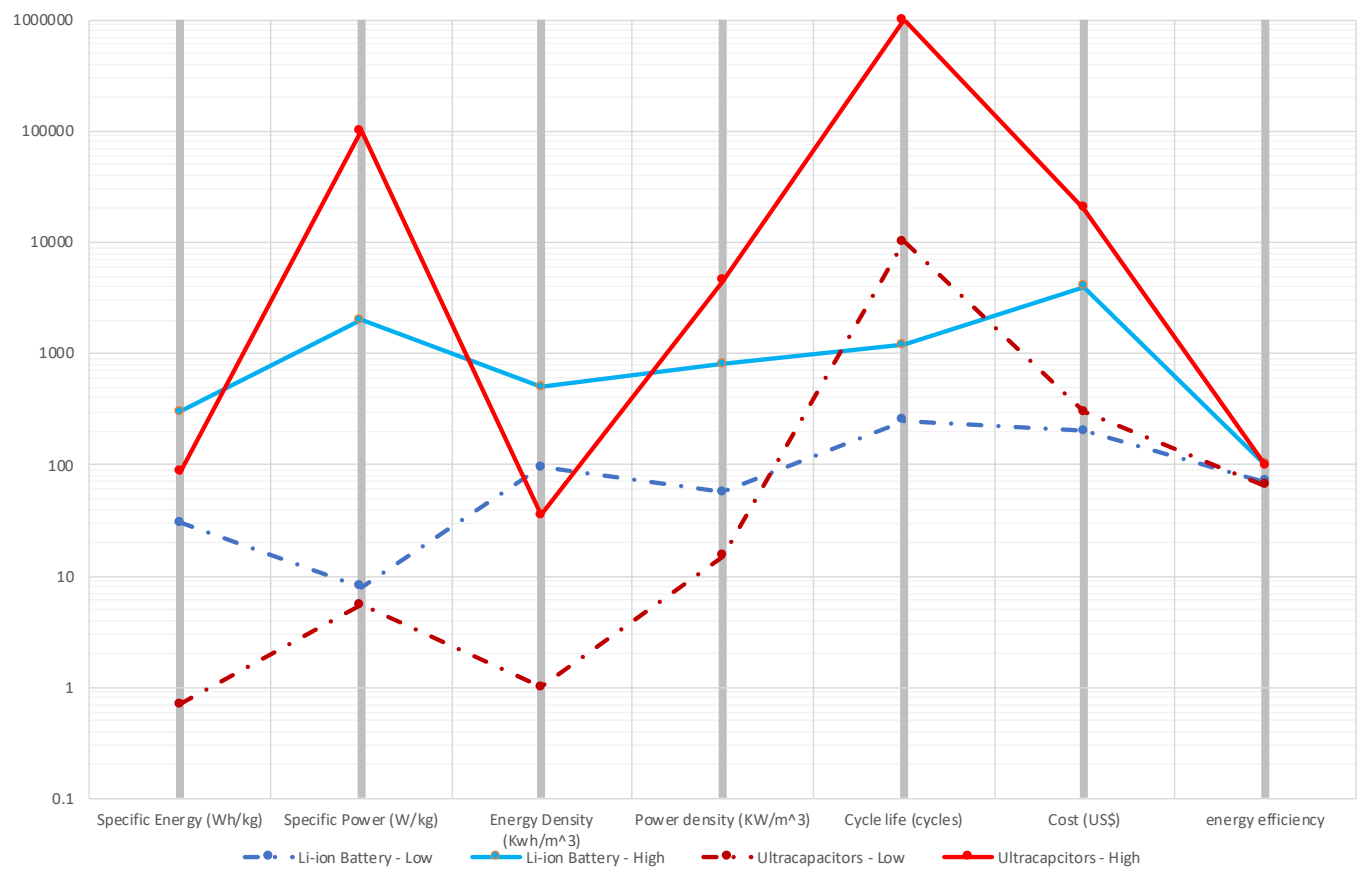

FIGURE 14 - LITHIUM-ION BATTERIES VS. ULTRACAPACITORS - LINE GRAPH

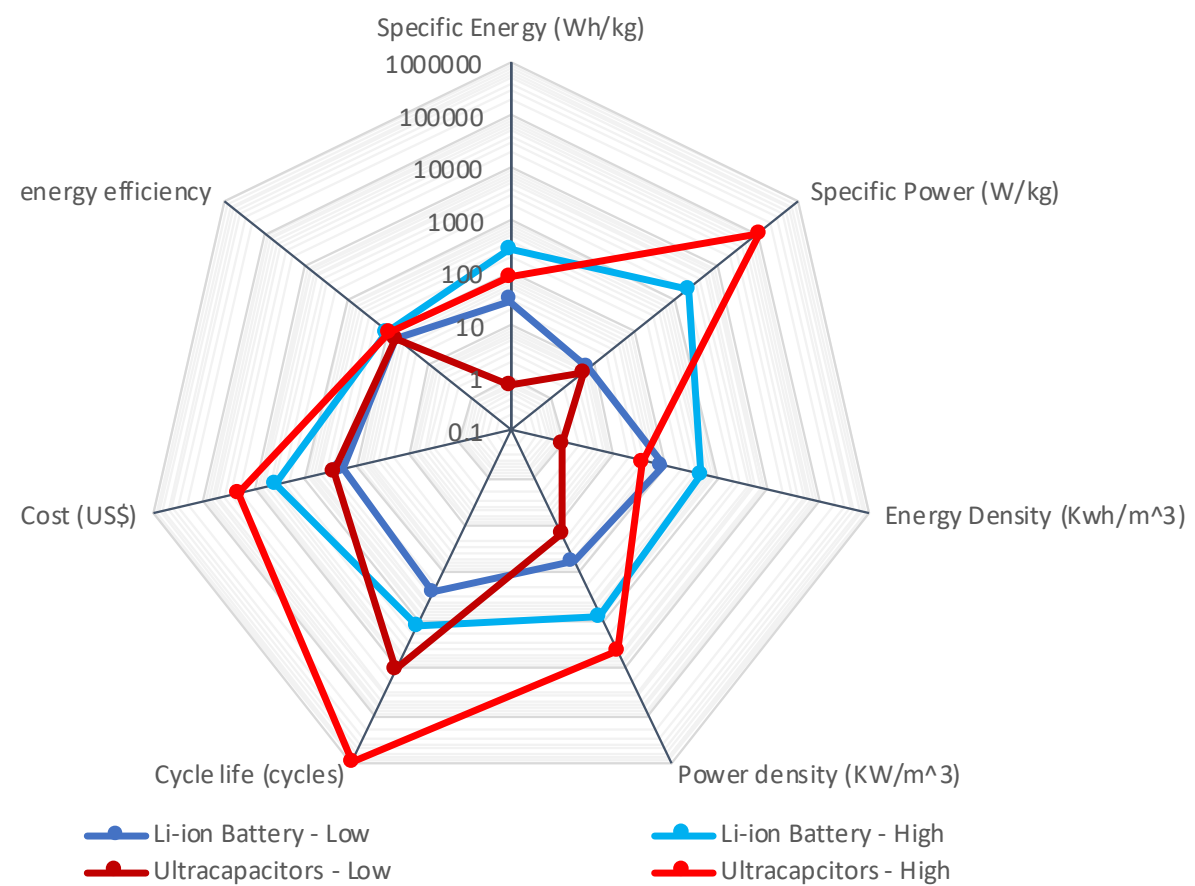

FigURE 15 - LITHIUM-ION BATTERIES VS. UltRACAPACITORS - SPIDER PLOT 


\section{BATTERY SUPERCAPACITOR HYBRIDS}

\section{INTRODUCTION}

Despite their different electrochemical characteristics and behaviors, batteries and SCs share similar configurations, both include anode, cathode, electrolyte, separator, and current collector, making the hybridization feasible. The following sections will explain what BSHs are, their development over the years, and categorize them based on the materials used for their construction. further, they will describe the differences between BSHs and LIBs/SCs and evaluate the benefits of a hybrid device.

\section{CONSTRUCTION}

A BSH is an energy storage system that uses one battery electrode in conjunction with a supercapacitor electrode. A BSH contains one reactive, battery type electrode and one capacitive electrode which can be either EDLC-type or pseudocapacitive. Both the battery and SC electrodes can be used as either anode or cathode. Despite being asymmetric, a BSH is different from conventional "asymmetric SCs," in which both electrodes are capacitive but with asymmetric capacitive charge storage mechanism. BSHs typically, by virtue of their hybrid nature, can surpass the energy density of conventional asymmetric SCs and could potentially outperform batteries with respect to their inherent power density limitations due to the combination of a capacitive electrode and the technologically mature battery electrode to warrant faster electrochemical kinetics. Further, the total theoretical capacitance of the capacitive electrode could be employed for practical applications and the range of possible output voltages could be widened through selecting an ideal battery-type electrode that can operate in a separated potential range. A diagrammatic representation of their construction is shown in figure 16 .

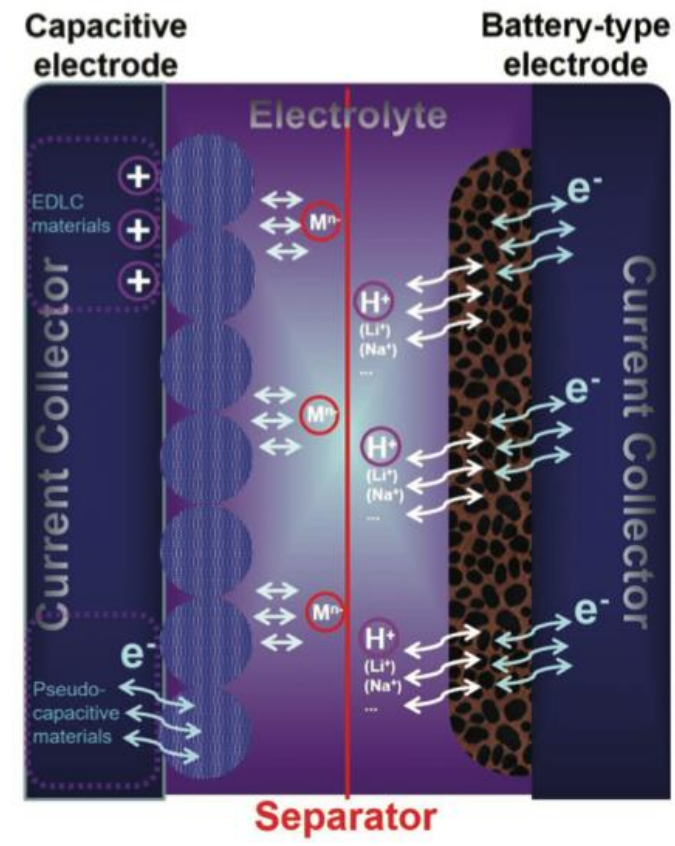

FIGURE 16 - REPRESENTATIVE CONSTRUCTION OF A GENERIC BSH

\section{CHARGE-DISCHARGE MECHANISM IN BSHS}

During charge and discharge, ions move between the two electrodes and the bulk of the redox reactions occur on the batterytype, reactive electrode. Ion accumulation and separation, which allow rapid charge transfer and thus the superior power densities that BSHs have, occur on the capacitive electrode. Simultaneously, there is an electron flow occurring on the external circuit connection which is the source of useful energy.

\section{Charge}

When a BSH is charged, several processes occur simultaneously. The following section will elaborate further. Figure $17^{29}$ displays differences in charge and discharge mechanisms of several different energy storage systems

\section{Charging the Capacitive electrode}

As current is passed through the battery, the electrolyte is ionized, and the anions formed from its dissociation are attracted to the capacitive electrode. Upon reaching the anode, they are ordered on the activated carbon, which, due to its porosity, has an extremely large surface area on which these ions can order themselves. This creates a negative charge on the anode and a positive charge in the electrolyte - which is now composed primarily of cations.

\section{Charging the reactive electrode}

This electrode functions similarly to that in a battery, where $\mathrm{Li}+$ ions are intercalated into a graphite/graphene electrode, but from the electrolyte instead of an oppositely charged electrode containing the Lithiated metal compound

\section{Discharge}

When the two terminals are connected, the capacitive electrode releases its electrostatically charged energy in conjunction with the reactive electrode. The energy is released at a high rate for a generally longer period than in a battery, due to the asymmetrical construction. By virtue of the electrostatic storage of charge in the capacitive electrode, it wants to release the charge as quickly as possible, but this release is restricted in ways by the relatively slower energy release mechanism in the reactive electrode - and a middle ground of discharge is reached
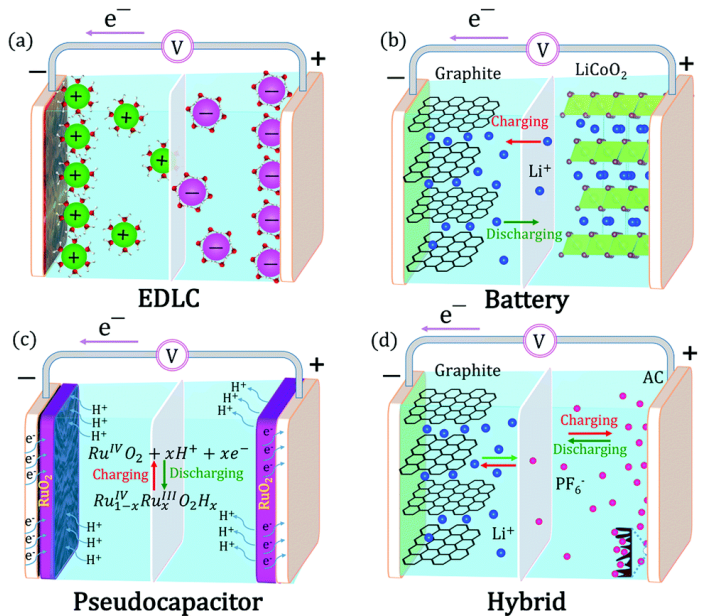

Hybrid

FIGURE 17 - DIAGRAMMATIC REPRESENTATIONS OF CHARGE-DISCHARGE (A) IN ELDC; (B) LIB; (C) PSEUDOCAPACITOR; (D) BSH 


\section{PROGRESS IN BSHS SINCE THEIR INVENTION}

One of the earliest hybrid SCs is the Li-ion based BSH, which was named, reported, and patented by Amatucci et $\mathrm{al}^{1}$. in 2001. $\mathrm{Li}$-ion $\mathrm{BSH}$ was assembled with a nanostructured $\mathrm{Li}_{4} \mathrm{Ti}_{5} \mathrm{O}_{12}$ anode and an activated carbon cathode. With the high specific capacity of Li-ion type electrode, $\mathrm{Li}$-ion BSHs bridged the gap between LIBs and SCs and attracted worldwide attention.

Li-ion BSHs were developed with the goal to have energy densities compared with supercapacitors while at the same time retaining the power and most importantly the notorious cycle life and robustness of a supercapacitor. To increase the energy density of the supercapacitor by a factor of 5-10 and maintain cycle robustness, a non-aqueous asymmetric hybrid configuration was developed incorporating a capacitive or pseudocapacitive positive electrode coupled with a Li-ion insertion. The most challenging properties to overcome was the ability to maintain $>100,000$ cycles and the ability to accept full charge within 15 seconds $^{30}$. For example, a composite/nanocomposite of $\mathrm{LiCoO} 2$ and activated carbon can be fabricated and applied as the positive electrode. The ratio of intercalation material and activated carbon further expanded the flexibility of the energy storage cell to be tuned to a specific device's requirement. The composite packaged cell exhibited $20-35 \mathrm{Wh} / \mathrm{kg}$ at $2000-3000 \mathrm{~W} / \mathrm{kg}$ as an experimental prototype in 2004, and was able to withstand over 3000 cycles $^{30}$ even with an output as considerable as that mentioned above. The ragone plot below (figure 18) shows the current and future potential for BSHs

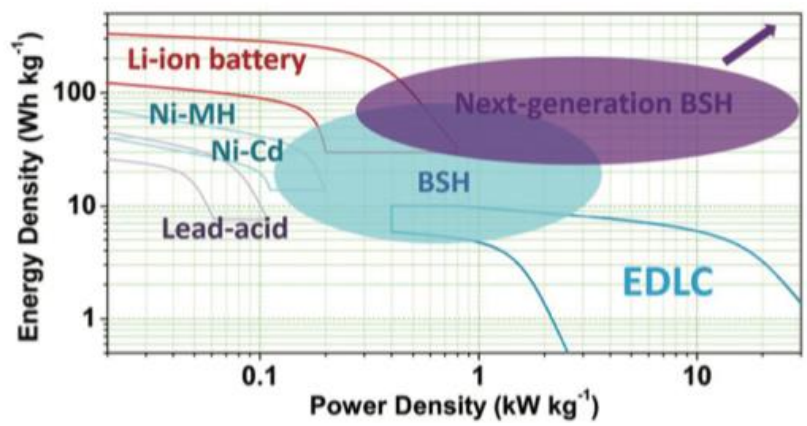

FIGURE 18 - RAGONE PLOTS OF VARIOUS RECHARGEABLE BATTERIES AND ELDC, AND THE COMPARISON WITH BSH

\section{COMPARING BSHS WITH CONVENTIONAL ENERGY STORAGE MECHANISMS}

This section will compare the electrochemical performance of BSHs, both those that currently exist and those whose prototypes are in the making, with the electrochemical performance of LIBs and UCs. By doing this, one can fully grasp the potential that BSHs hold and why they could be the ideal power storage mechanism when completely developed. This comparison is carried out in table 4 , with diagrammatic representations through figures 19 and 20 .

\begin{tabular}{|c|c|c|c|c|}
\hline & $\begin{array}{l}\text { Li-Ion } \\
\text { Batteries }{ }^{23}\end{array}$ & Ultracapacitors ${ }^{23}$ & $\begin{array}{l}\text { BSHs - } \\
\text { current } \\
\text { generation }^{31}\end{array}$ & $\begin{array}{l}\text { BSHs - } \\
\text { future } \\
\text { generation }{ }^{31}\end{array}$ \\
\hline $\begin{array}{l}\text { Specific } \\
\text { Energy } \\
(\mathrm{Wh} / \mathrm{kg})\end{array}$ & $30-400$ & $0.7-85.6$ & $25-200$ & $50-500$ \\
\hline $\begin{array}{l}\text { Specific } \\
\text { Power } \\
(\mathrm{W} / \mathrm{kg})\end{array}$ & $8-2000$ & $5.44-100000$ & $400-5000$ & $1000-20000$ \\
\hline $\begin{array}{l}\text { Cycle life } \\
\text { (cycles) }\end{array}$ & $250-1200$ & $10000+$ & $10000+$ & $10000+$ \\
\hline
\end{tabular}

TABLE 4 - COMPARING THE ELECTROCHEMICAL PERFORMANCE OF BSHS WITH LIBS AND UCS

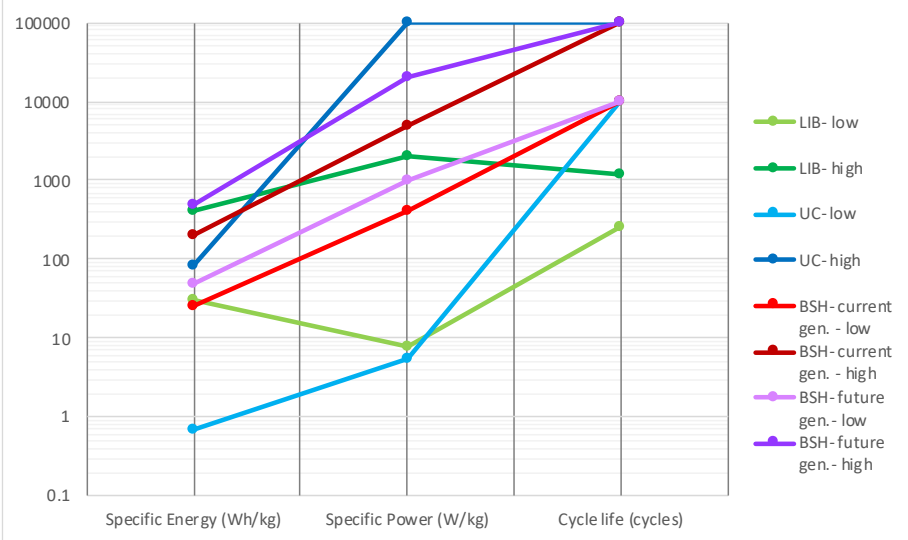

FIGURE 19 - COMPARING ELECTROCHEMICAL PERFORMANCE OF LIBS, UCS AND BSHS

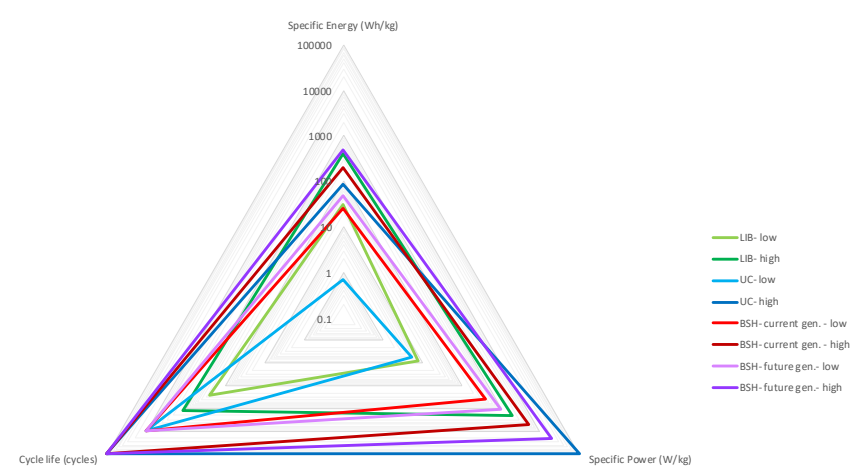

FIGURE 20 - ALTERNATIVE REPRESENTATION FOR THE COMPARISON OF ELECTROCHEMICAL PERFORMANCE OF LIBS, UCS, BSHS

\section{TYPES OF BATTERY-SUPERCAPACITOR HYBRIDS}

\section{Li-ion BSH}

With almost the lowest lithium intercalation potential and highest cycling stability among all viable Li-ion anodes, prelithiated carbon materials such as graphite are one of the most suitable anodes for organic Li-ion BSHs. Li-ion BSHs assembled using battery-type lithium-intercalation cathode and capacitive carbon anode are also advantageous and generally have high working potentials, due to the high-voltage plateau of the cathode. $^{15}$

Anode materials such as Ti-based oxides ${ }^{\mathrm{i}}$, silicon $^{32}, \mathrm{Fe} 3 \mathrm{O}^{33}$, and intercalated carbon, and cathode materials of spinel 
$\mathrm{LiMn}_{2} \mathrm{O}_{4}{ }^{34} \mathrm{Li}_{2} \mathrm{CoPO}_{4} \mathrm{~F}^{35}$ and their hybrids with various conducting carbon/polymers were investigated for $\mathrm{Li}$-ion $\mathrm{BSHs}{ }^{31}$

Zhang et al. ${ }^{36}$ applied commercial activated carbon as the cathode and mesocarbon microbeads as the anode, achieving a maximum power density of $5500 \mathrm{~W} / \mathrm{kg}$ and energy density of 92.3 $\mathrm{Wh} / \mathrm{kg}$.

Nanostructured hybrid electrodes represent a promising avenue to obtain advanced energy storage devices with excellent performance. With this, enhanced electrochemical properties such as fast charge transfer kinetics and ultralong cycling stability were realized. ${ }^{31}$ Further, Metal oxide nanostructures are promising electrode materials for lithium-ion batteries and supercapacitors because of their high specific capacity/capacitance, typically 2-3 times higher than that of the carbon/graphite-based materials.

For example, hybridized nanostructured electrodes of batterytype materials with advanced carbon were demonstrated the most effective to achieve ultrafast charging and discharging. Li4 Ti5 O12 -based Li-ion BSH is the most widely studied hybrid device since the Ti-based anodes can completely avoid the electrolyte decomposition ${ }^{\text {ii }}$

Naoi et al. ${ }^{37}$ utilized "ultracentrifuging treatment" to attain "nano-Li4 Ti5 O12 /carbon" anode. This nanoelectrode even showed a high capacity of $78 \mathrm{mAh} / \mathrm{g}$ at $1200 \mathrm{C}$ rate $(3 \mathrm{~s}$ chargedischarge) and the full cell could reach an energy density of 28 $\mathrm{Wh} / \mathrm{L}$ at $10 \mathrm{~kW} / \mathrm{L}$, which shed light on how to design highperformance battery-type electrodes for BSHs. A similar concept was also demonstrated for $\mathrm{Nb}_{2} \mathrm{O}_{5}$ anodes ${ }^{38,39}$; with the design of mesoporous or core-shell structured $\mathrm{Nb} 2 \mathrm{O} 5$ /carbon anodes, the BSH devices exhibited very high power densities, at which high energy densities were still maintained (eg: $16 \mathrm{Wh} / \mathrm{kg}$ at $18 \mathrm{~kW} / \mathrm{kg}$ )

Although the specific capacity of intercalation cathode is lower than most of the battery anodes, it still has much higher charge storage ability as compared to the capacitive cathodes in EDLC device and shows great promise to boost the energy density of the $\mathrm{BSHs}^{31}$.

Brandt et $\mathrm{al}^{40}$. reported a high-power Li-ion $\mathrm{BSH}$ based on LiNi0.5 Mn1.5 O 4 and activated carbon; with the cell voltage of $0-3.3 \mathrm{~V}$, this device showed capacity retention of $89 \%$ after 4000 cycles, maintaining average specific energy density and power density of $\sim 50 \mathrm{Wh} / \mathrm{kg}$ and $\sim 1100 \mathrm{~W} / \mathrm{kg}$ respectively

Aqueous Li-ion BSHs is another attractive hybrid device due to the high safety (non-volatile, non-flammable, and nontoxicity) and high ionic conductivity of aqueous electrolytes as well as the simplified device assembly process ${ }^{31}$.

\section{Na-ion BSH}

LIBs have had a monopoly on the electrochemical energy storage sector for portable devices since the 1990s. although they have their benefits, the lithium supply is severely limited, and its extraction is an expensive process. Sodium, however, is present in abundance and due to similar chemical properties to lithium, it provides a viable alternative to Li-ion batteries. Sodium-ion based storage systems are not in their embryonic stage technologically, with the earliest sodium intercalation material $\left(\mathrm{TiS}_{2}\right)$ reported in $1980^{41}$. More recently, $\mathrm{O}_{3}$ layered metal oxide cathodes were demonstrated as potential electrode materials for $\mathrm{Na}$-ion batteries. $^{42}$
Combining the merits of both Li-ion BSHS, and Na-ion batteries, Na-ion BSHs have been the subject of intensive development over the past decade. The configuration of the device can be similar to that of Li-ion BSHs with either organic or aqueous electrolytes. Accordingly, carbon//carbon matching - a non-expensive way to coat carbon on the Na-metal oxide electrodes. This has been widely investigated in the development of NA-ion BSHs. Carbon coatings on the electrodes have the potential to double their cycle life ${ }^{43}$ - with Superior cyclic stability of the carbon coated product with capacity retention of more than $80 \%$ after 1000 cycles of charging/discharging demonstrated with an optimum carbon thickness matching commercial samples. ${ }^{43}$ However, due to the relatively low capacity of hard carbon in Na-ion electrolyte, the electrochemical performance of the device is inferior to that obtained in Li-ion electrolyte. To improve the device's performance, the delicate design of micro-/nanostructures of electrodes is very important. In general, fast $\mathrm{Na}$ intercalation kinetics and high surface area should be ensured for the reactive carbon anode and capacitive carbon cathode, respectively. ${ }^{31}$

very low potential hysteresis between charge and discharge processes was attained for anode and ideal EDLC behavior of the cathode was achieved by Ding et al. ${ }^{44}$ in 2015 . The group assembled a carbon//carbon Na-ion BSH, with both electrodes derived from peanut shells, resulting in highly flaky, thin, and porous carbon materials. The anode carbon was designed with partially ordered thin graphene domains while cathode carbon was with large surface area and high levels of oxygen doping, providing fast $\mathrm{Na}+$ diffusion and abundant redox active sites as well as massive ion accumulation and pseudocapacitive reaction. Consequently, this $\mathrm{Na}$-ion $\mathrm{BSH}$ exhibited excellent power and energy densities (201, 76, and $50 \mathrm{Wh} \mathrm{kg}-1$ at 285, 6500, and 16 $500 \mathrm{~W} \mathrm{~kg}-1$, respectively). ${ }^{44}$

\section{CONCLUSION}

This literature review has elaborated on the workings of BSHs and LIBs and UCs. Diagrams and illustrations were used to simplify concepts introduced and explained throughout this paper. A tabular format was used where possible to assist the comprehension of the data presented - with visual representations present for the same purpose. Lithium-ion batteries, while a good means of energy storage will be outperformed by Lithium-Sulfur and Lithium-air batteries when they have been developed fully due to them being more cost-effective, the raw materials being more abundant and most importantly because of better electrochemical performance. However, Battery-supercapacitors hybrids can be derived from these Li-based batteries as well, opening avenues for research on BSHs. BSHs are high performing energy storage systems, but they do no match the specific power of ultracapacitors - leading me to believe that for applications that require high specific power systems, a bank of UCs should be used - at least until BSHs are developed sufficiently to compete with UCs. 


\section{REFERENCES}

1. Amatucci, G. G., Badway, F., Pasquier, A. D. \& Zheng, T. An Asymmetric Hybrid Nonaqueous Energy Storage Cell. J. Electrochem. Soc. 148, A930 (2001).

2. Kuratani, K. et al. Na-ion capacitor using sodium predoped hard carbon and activated carbon. Electrochimica Acta 76, 320-325 (2012).

3. Alkaline cell diagram - brittanica.com.

4. Li-ion battery diagram - colourbox.com.

5. Goonan, T. G. Lithium Use in Batteries. (2012).

6. Abruña, H. D., Kiya, Y. \& Henderson, J. C. Batteries and electrochemical capacitors. Phys. Today 61, $43-47$ (2008).

7. Zhou, W. HIGH CAPACITY METAL-BASED ANODES FOR LITHIUM-ION BATTERIES. 165.

8. Massé, R. C., Liu, C., Li, Y., Mai, L. \& Cao, G. Energy storage through intercalation reactions: electrodes for rechargeable batteries. Natl. Sci. Rev. 4, 26-53 (2017).

9. Zhang, T., Li, D., Tao, Z. \& Chen, J. Understanding electrode materials of rechargeable lithium batteries via DFT calculations. Prog. Nat. Sci. Mater. Int. 23, 256-272 (2013).

10. Zhao, H. Lithium Titanate-Based Anode Materials. in Rechargeable Batteries (eds. Zhang, Z. \& Zhang, S. S.) 157-187 (Springer International Publishing, 2015). doi:10.1007/978-3319-15458-9_6.

11. Khalid, A., Khushnood, R. A., Saleem, S., Farooq, S. Z. \& Shaheen, N. Improving the mechanical properties of cementitious composites with graphite nano/micro platelets addition. IOP Conf. Ser. Mater. Sci. Eng. 431, 062005 (2018).

12. Amatucci, G. G., Tarascon, J. M. \& Klein, L. C. CoO2, The End Member of the Li x CoO2 Solid Solution. J. Electrochem. Soc. 143, 1114-1123 (1996).

13. Somo, T. R. et al. A Comparative Review of Metal Oxide Surface Coatings on Three Families of Cathode Materials for Lithium Ion Batteries. Coatings 11, 744 (2021).

14. Peterson, S. B., Apt, J. \& Whitacre, J. F. Lithium-ion battery cell degradation resulting from realistic vehicle and vehicle-to-grid utilization. J. Power Sources 195, 2385-2392 (2010).

15. Wu, Y. \& Cao, C. The way to improve the energy density of supercapacitors: Progress and perspective. Sci. China Mater. 61, 1517-1526 (2018).

16. Boruah, B. D. \& Misra, A. Internal Asymmetric Tandem Supercapacitor for High Working Voltage along with Superior Rate Performance. ACS Energy Lett. 2, 1720-1728 (2017).

17. Bruce, P. G., Freunberger, S. A., Hardwick, L. J. \& Tarascon, J.-M. Li-O2 and $\mathrm{Li}-\mathrm{S}$ batteries with high energy storage. Nat. Mater. 11, 19-29 (2012).

18. Dubarry, M. \& Liaw, B. Y. Identify capacity fading mechanism in a commercial LiFePO4 cell. J. Power Sources 194, 541-549 (2009).

19. Jeong, G., Kim, Y.-U., Kim, H., Kim, Y.-J. \& Sohn, H.J. Prospective materials and applications for $\mathrm{Li}$ secondary batteries. Energy Environ. Sci. 4, 1986 (2011).

20. Smart Sensors Networks. (Elsevier, 2017). doi:10.1016/C2015-0-05917-2.

21. May-Ying Chu, De Jonghe, L. \& Visco, S. High specific power lithium polymer rechargeable battery. in Proceedings of 11th Annual Battery Conference on Applications and Advances 163-165 (IEEE, 1996). doi:10.1109/BCAA.1996.484988.

22. Zhang, J., Zhou, Q., Tang, Y., Zhang, L. \& Li, Y. Zincair batteries: are they ready for prime time? Chem. Sci. 10, 89248929 (2019).

23. Sabihuddin, S., Kiprakis, A. \& Mueller, M. A Numerical and Graphical Review of Energy Storage Technologies. Energies 8, 172-216 (2014).

24. Cole, W. \& Frazier, A. W. Cost Projections for UtilityScale Battery Storage: 2020 Update. Renew. Energy 21 (2020).

25. Hsieh, I.-Y. L., Pan, M. S., Chiang, Y.-M. \& Green, W. H. Learning only buys you so much: Practical limits on battery price reduction. Appl. Energy 239, 218-224 (2019).

26. Li, K. \& Tseng, K. J. Energy efficiency of lithium-ion battery used as energy storage devices in micro-grid. in IECON 2015 - 41st Annual Conference of the IEEE Industrial Electronics Society 005235-005240 (IEEE, 2015). doi:10.1109/IECON.2015.7392923.

27. Salameh, Z. M. \& Kim, B. G. Advanced lithium polymer batteries. in 2009 IEEE Power \& Energy Society General Meeting 1-5 (IEEE, 2009). doi:10.1109/PES.2009.5275404.

28. Hoffart, F. Proper Care Extends Li-Ion Battery Life. 5 (2008).

29. El-Kady, M. F., Rahmanifar, M. S., Kaner, R. B., Mousavi, M. F. \& noori, A. Towards establishing standard performance metrics for batteries, supercapacitors and beyond. Chem. Soc. Rev. 48, 1272-1341 (2019).

30. Plitz, I. et al. Recent Advances of Alternative High Power Nonaqueous Chemistries based on Li4 Ti5 O 12 Negative Electrodes. (2004).

31. Zuo, W. et al. Battery-Supercapacitor Hybrid Devices: Recent Progress and Future Prospects. Adv. Sci. 4, 1600539 (2017).

32. Liu, X. et al. Silicon/copper dome-patterned electrodes for high-performance hybrid supercapacitors. Sci. Rep. 3, 3183 (2013).

33. Zhang, F. et al. A high-performance supercapacitorbattery hybrid energy storage device based on graphene-enhanced electrode materials with ultrahigh energy density. Energy Environ. Sci. 6, 1623 (2013).

34. Raja, M. W., Mahanty, S. \& Basu, R. N. Filter paper templated interconnected nanocrystalline LiMn2O4 with high coulombic efficiency and rate capability. J. Mater. Chem. 19, 6161 (2009).

35. Karthikeyan, K. et al. A high performance hybrid capacitor with Li2CoPO4F cathode and activated carbon anode. Nanoscale 5, 5958 (2013).

36. Zhang, J., Liu, X., Wang, J., Shi, J. \& Shi, Z. Different types of pre-lithiated hard carbon as negative electrode material for lithium-ion capacitors. Electrochimica Acta 187, 134-142 (2016).

37. Naoi, K., Naoi, W., Aoyagi, S., Miyamoto, J. \& Kamino, T. New Generation "Nanohybrid Supercapacitor". Acc. Chem. Res. 46, 1075-1083 (2013).

38. Lim, E. et al. Facile Synthesis of Nb 2 O 5 @arbon Core-Shell Nanocrystals with Controlled Crystalline Structure for High-Power Anodes in Hybrid Supercapacitors. ACS Nano 9, 7497-7505 (2015). 
39. Lim, E. et al. Advanced Hybrid Supercapacitor Based on a Mesoporous Niobium Pentoxide/Carbon as High-Performance Anode. ACS Nano 8, 8968-8978 (2014).

40. Brandt, A. et al. Investigations about the Use and the Degradation Mechanism of LiNi0.5Mn1.5O4in a High Power LIC. J. Electrochem. Soc. 161, A1139-A1143 (2014).

41. Newman, G. H. \& Klemann, L. P. Ambient Temperature Cycling of an Nalhspace0.167em-lhspace0.167emTiS2 Cell. J. Electrochem. Soc. 127, 2097-2099 (1980).

42. $\mathrm{Wu}, \mathrm{X}$. et al. Unraveling the storage mechanism in organic carbonyl electrodes for sodium-ion batteries. Sci. Adv. 1, e1500330 (2015).

43. Vasu, S., Sahana, M. B., Sudakar, C., Gopalan, R. \& Sundararajan, G. In-situ carbon encapsulation of LiNi1/3Co1/3Mn1/3O2 using pillared ethylene glycol trapped in the metal hydroxide interlayers for enhanced cyclic stability. Electrochimica Acta 251, 363-377 (2017).

44. Ding, J. et al. Peanut Shell Hybrid Sodium Ion Capacitor with Extreme Energy - Power Rivals Lithium Ion Capacitors. Environ. Sci. 47. 